\title{
Form over Substance? China's Contribution to Human Rights through Universal Periodic Review
}

\author{
Rhona Smith
}

\section{INTRODUCTION}

This article will analyse the Chinese contribution to the first cycle of the Human Rights Council's universal periodic review. In 2006, the then new U.N. Human Rights Council ${ }^{2}$ was tasked with establishing the modalities of a universal periodic review of compliance by all U.N. member states with human rights and humanitarian law, irrespective of which treaties any state has elected to ratify. The Universal Declaration of Human Rights and voluntary commitments of states can be used to discern the salient human rights standard, filling any gaps in a state's framework of human rights' obligations derived from their treaty ratifications. China was a vocal member of the Like Minded Group in the U.N. during this formative period and succeeded in securing a General Assembly, then Human Rights Council, resolution which reflected the group's view of universal periodic review.

An integral part of the review process is "peer review" of the performance of states by other states. China has been very active during this inter-governmental process, contributing to the majority of reviews. There is some literature and civil society reports on China's experience of universal periodic review, on universal periodic review generally, and on China's engagement with the U.N. and international human rights. However, there is no detailed qualitative analysis of the approach China took to its interventions in the interactive dialogue of other states. This article will fill that gap. Using the comments made on behalf of China in all peri-

\footnotetext{
1 Professor of International Human Rights, Northumbria University. This article was submitted and accepted for publication in 2012.

2 G.A. Res. 60/251, U.N. GAOR, 60th Sess., U.N. Doc. A/RES/60/251 (Apr. 3, 2006).
} 
odic reviews (taken as the reports of the working group on the interactive dialogue element of the review ${ }^{3}$ ), an attempt will be made to categorise the comments made by China. It will thus be possible to discern the nature of rights and issues China elected to focus on during its interventions. It will be interesting to see whether this matches areas identified by China in its voluntary human rights commitments, rights and freedoms expressed in treaties ratified, the millennium development goals and other documentation. Moreover it will be instructive to compare the areas identified by China for comment with those areas identified as areas of progress or concern by third states in China's own periodic review.

The article concludes with some observations on whether China's approach to the first cycle of universal periodic review embodies "form" (overt participation), over "substance," and thus whether or not China is making a meaningful contribution to the advancement of human rights through this mechanism.

\section{UNIVERSAL PERIODIC REVIEW}

China is perhaps not regarded as the most fervent advocate of international human rights' standards, and the international (UN) monitoring systems. ${ }^{4}$ Perhaps it is thus surprising that China has proven to be a very enthusiastic participant in the newest human rights monitoring system, universal periodic review. Indeed, as will be seen, China has proven to be one of the most active and most positive participants in the world. This development sits alongside the growth in stature of China on the international stage, joining the World Trade Organisation in 2001 and embracing human rights

3 All key documentation on universal periodic review is in the public domain, available at www.ohchr.org. Note that this article uses the English language version of all documents, where unavailable, the French language version was used as an alternative.

4 A number of NGOs regularly criticise China's human rights performance, as do a number of States - for perhaps predictable examples, see Amnesty International: China, http://www.amnesty.org/en/region/china; Human Rights Watch: China and Tibet, http://www.hrw.org/asia/china; U.S. Department of State, Annual Human Rights Reports - Latest Report on China, available at http://www.state. gov/documents/organization/186478.pdf. China refutes most, if not all, the claims made. 
as a concept, albeit perhaps with "Chinese characteristics."5

During the formative stages of the Council (pre and post-establishment), China led the Like Minded Group ${ }^{6}$ who were against singling out any states for criticism or comment within the new Council. ${ }^{7}$ In such a way, it was proposed that the Council would establish itself as different from the Commission, which latterly was besmirched by allegations of bias and selective persecution or condoning of states on factors more attributable to that states' allies and power base rather than purely on the facts available. ${ }^{8}$ During a meeting between the General Assembly President and the (now former) Commission of Human Rights, China's ambassador conveyed the views of the Like Minded Group, welcoming the decision of the General Assembly to create the Human Rights Council: "Human rights is not about

See, e.g., Information Office of the State Council of the People's of Republic of China, Human Rights in China (1991), available at http://www. china.org.cn/e-white/7/index.htm. Part X of this elaborates China’s involvement in International Human Rights activities: "Consideration should be given to the differing views on human rights held by countries with different political, economic and social systems, as well as different historical, religious and cultural backgrounds. International human rights activities should be carried on in the spirit of seeking common ground while reserving differences, mutual respect, and the promotion of understanding and cooperation."

6 Algeria, Bangladesh, Belarus, Bhutan, Cuba, Egypt, India, Indonesia, Iran, Malaysia, Myanmar, Nepal, Pakistan, the Philippines, Sri Lanka, Sudan, Syria, Viet Nam, and Zimbabwe.

7 For a more detailed exposition of this, see Philip Alston, Reconceiving the UN Human Rights Regime: Challenges confronting the new UN Human Rights Council, 7 Melbourne Journal of International Law (2006).

8 See, e.g., The Secretary-General, In Larger Freedom: Towards development, security and human rights for all, U.N. Doc. A/59/2005 (Mar. 21, 2005); Henning Boekle, Western States, the UN Commission on Human Rights, and the '1235' Procedure: The question of bias revisited, 13 Netherlands Quarterly of Human Rights 367 (1995); and more recently, see Patrizia Scanella \& Peter Splinter, The United Nations Human Rights Council: A promise to be fulfilled, 7 Human Rights Law Review 41 (2007); Nico Schrijver, The UN Human Rights Council: A new 'society of the committed' or just old wine in new bottles?, 20 LEIDEN JOURNAL OF INTERNATIONAL LAW 809 (2007). 
the preach and the preached, the condemn and the condemned." That the Commission ceased to be a credible human rights body appeared agreed, opinions on how best to ameliorate the situation differed. Nevertheless, a major cultural shift from the perceived practice of the Commission ${ }^{10}$ was supported by the Like Minded Group and, indeed, most of the United Nations' membership. ${ }^{11}$

The Council was established and held its first session in June 2006, by which time the Economic and Social Council had disbanded its Commission on Human Rights. With a more transparent, geographically representative membership, China offered its candidature for election to membership of the inaugural Council. ${ }^{12}$ It was duly elected, with its membership renewed for a further three years. ${ }^{13}$ Note that it is no longer a member as the rules prevent any state from serving more than two consecutive terms. ${ }^{14}$ Of course, China can present its candidature thereafter should, as seems highly probable, the government so desire. (The former Commission had no such restriction; thus some states sat on it for a decade or more, others almost permanently.) Many functions of the Commission were taken on (subject to a review and rationalisation process) by the Council. However, the Council also had some new functions, powers and responsibilities, reflecting in part the shift in emphasis from the Commission to the Council and the perceived needs of the international community almost sixty years

9 Statement by H.E. Ambassador SHA Zukang, on behalf of the Like Minded Group, at the Meeting between the President of the General Assembly and the Commission on Human Rights, Nov. 25, 2005.

10 China was a member of the Commission from 1981, having previously attended as an observer.

11 Indeed, only Israel, USA, Palau and the Marshall Islands voted against G.A. Res. 60/251, with Belarus, Iran and Venezuela abstaining.

12 The Council has forty-seven Member States, elected taking into account their contribution to the promotion and protection of human rights, their voluntary pledges and other human rights commitments (G.A. Res. 60/251, supra note 2, ๆๆ 7-8).

13 For the Note Verbale on Pledges and Commitments of the Chinese Government leading up to the second election, see U.N. GAOR, 63d Sess. 83d pleb. mtg, U.N. Doc. A/63/840 (Apr. 30, 2009).

14 G.A. Res. 60/251, supra note 2, 7. 
after the Commission drafted the Universal Declaration of Human Rights, establishing the basis for the modern international human rights system.

Perhaps the major innovation in the General Assembly resolution establishing the Human Rights Council in $2006^{15}$ was the introduction of universal periodic review as a mechanism for considering "the fulfilment by each State of its human rights obligations and commitments in a manner which ensures universality of coverage and equal treatment with respect to all States." ${ }^{\prime 6}$ Universal periodic review, applying equally to all states, is clearly in keeping with the anti-selectivity stance evinced by the Like Minded Group, ${ }^{17}$ which certainly influenced the formative stages of development. Arguably the final text of GA resolution 60/251 and, indeed, the further elucidation of the modalities of review in Human Rights Council resolution 5/1 (the institution-building resolution) ${ }^{18}$ reflects China's idea of a more supportive environment to encourage the promotion and protection of human rights. This found expression in the founding resolution ("the work of the council shall be guided by the principles of ... impartiality, objectivity and non-selectivity, constructive international dialogue and cooperation"19) and the institution-building resolution of the Council itself ("the universal periodic review should: . . be conducted in an objective, transparent, non-selective, constructive, non-confrontational and non-politicised manner" ${ }^{20}$ ).

Universal periodic review is the only human rights monitoring system to which every U.N. Member state submits. This process is compulsory, in

15 G.A. Res. 60/251, supra note 2.

16 Id. 5(e). For a discussion of this process, see, inter alia, Felice Gaer, A Voice not an Echo: Universal periodic review and the UN treaty body system, 7(1) HUMAN Rights Law Review 109 (2007); Nadia Bernaz, Reforming the UN Human Rights Protection Procedures: A legal perspective on the establishment of the Universal Periodic Review mechanism, in New Institutions For Human Rights Protection 75-92 (K. Boyle ed., Oxford University Press 2009).

17 Statement by SHA, supra note 9.

18 Human Rights Council Res. 5/1 Institution-building of the New Human Rights Council, U.N. Human Rights Council, 9th mtg, U.N. Doc. A/HRC/RES/5/1 (June 18, 2007).

19 G.A. Res. 60/251, supra note 2, 4.

20 Human Rights Council Res 5/1, supra note 18, ๆ 3(g). 
terms of the enabling resolution (GA Res 60/251), and comparatively new: the first cycle, covering all states, began in 2008 and completed late 2011 (twelve sessions were held); the second cycle has only just commenced (its first session was held May/June 2012). Indeed, perhaps to the surprise of sceptics, every U.N. member state complied with the new obligation to participate in the process, whether or not they voted in favour thereof during the initial U.N. General Assembly debates. Haiti was the only state to seek an exception, the exceptional circumstance of the earthquake of 2010 being sufficient to move Haiti from its initial scheduled review to the last session (October 2011). Every other state participated as and when scheduled, although a few states were not able to submit the national report in time and thus attested orally to their human record. ${ }^{21}$ On paper, therefore, the mechanism delivered - for the first time the U.N. secured a complete set of documentation on human rights in each and every member state. Inevitably the veracity of all the material can be questioned and, of course, the efficacy of peer review as a mechanism for ensuring respect for, and protection of, human rights is not yet clear. However, what is beyond debate is that no other U.N. system captures such information and self-evaluations of human rights in each and every state. ${ }^{22}$

This universal periodic review process is predicated on peer review, with each state submitting a national self-evaluation report of the human rights situation pertaining in its jurisdiction. ${ }^{23}$ This information is supplemented by two documents prepared by the Office of the High Commissioner for Human Rights: a compilation of information on the

21 See, e.g., U.N. Human Rights Council, Report of the Working Group on the Universal Periodic Review Cape Verde, ๆ 5, U.N. Doc. A/HRC/10/81 (Jan. 12, 2009) (statement by the head of delegation from the Ministry of Justice on the barriers to submitting a national report). South Africa submitted an oral national report to the first session of the first cycle. See U.N. Human Rights Council, Report of the Working Group on the Universal Periodic Review South Africa, ๆ 3(a), U.N. Doc. A/HRC/8/32 (May 23, 2008).

22 Few states have ratified every core U.N. human rights treaty and submit promptly to reviews of the fulfilment of their treaty obligations by the salient expert treaty monitoring bodies. The treaty body mechanism is thus, by definition patchy, being predicated on ratification by States of treaties.

23 See Human Rights Council Res. 5/1, supra note 18, ๆ15 for specification of the documentation on which the review focuses. 
state gathered from pre-existing U.N. treaty body, specialized agency and other reports; and "additional, credible and reliable information" provided by other stakeholders including, for example, non-governmental organizations. $^{24}$ Three Human Rights Council member states are selected (by lot) as rapporteurs to lead each review. ${ }^{25}$ Central to the actual review is a working group during which interactive dialogue between the state under review and the Council takes place. Over the course of some three hours, ${ }^{26}$ any U.N. member state (or observer state ${ }^{27}$ ) can seek to make comments, recommendations or raise questions on the human rights situation within the state under review, with the state given appropriate opportunity to respond during the working group session and, following due consideration, thereafter. The rapporteur states then oversee the drafting of a report of

24 The Like Minded Group indicated support for improving the participation of NGOs in the work of the Council - see SHA, supra note 9. During China's own review, over sixty stakeholders, alone or in collation with others, contributed to the stakeholder's comments. See U.N. Human Rights Council, Working Group on the Universal Periodic Review, Summary Prepared by The Office of the High Commissioner For Human Rights, in accordance with paragraph 15 (C) of the Annex to Human Rights Council Resolution 5/1, People's Republic of China (Including Hong Kong and Macao Special Administrative Regions (HKSAR) and (MSAR)), U.N. Doc. A/HRC/WG.6/4/CHN/3 (Jan. 5, 2009). Of these, several groups were recognised by the U.N. Economic and Social Council as having non-governmental status, including the All China Women's Federation in Beijing, China Family Planning Association, Beijing, and the China Society for Human Rights Study in China, Human Rights Watch (Switzerland) and Amnesty International (UK) - the latter two are, of course, not recognised in China. Several others were in China, including China Human Rights Lawyers Concern Group, Hong Kong Human Rights Commission (a collation of NGOs based in Hong Kong), Centre for the Study of Human Rights at Nankai University, Tianjin and the Institute of Law, Chinese Academy of Social Sciences, Beijing. Of course, a number of other stakeholders were located outwith China with views generally not accepted by China - Amnesty International and Human Rights Watch were mentioned above, and other examples include the Centre of Housing Rights and Evictions (Switzerland), the Tibetan UPR forum (a coalition), the World Uyghur Congress (USA) and the Falun Gong Human Rights Working Group (USA).

25 Human Rights Council Res. 5/1, supra note 18, ๆ 18.

26 The time limits are intended to insure a degree of parity of treatment of all States.

27 Palestine and the Holy See made contributions to several reviews. 
the working group on each state under review - these reports record the interventions made by all states and thus form the basis of the present analysis. This report and responses by the state under review are remitted to the full Human Rights Council for discussion (the state under review is invited to be present and NGOs can make comments at this juncture). A decision of the Human Rights Council adopts the final outcome of the review. The latter (final outcome) is a "perfunctory statement" 28 that the review has been conducted and comprises the documents noted above along with any comments of the state under review.

As is apparent, the interactive dialogue "peer review" 29 aspect of the process is key to ensuring all states are treated the same and to rendering the review transparent. ${ }^{30}$ Such a public forum also enables monitoring. The mechanism is "cooperative" rather than censorial and should fully involve the state under review with due consideration of "capacity-building needs" of the state. ${ }^{31}$ This reflects the views of the Like Minded Group and, indeed, others: Neumayer notes that "for the most part, countries take relatively little interest in the extent of human rights violations in other countries." 32 Universal periodic review has been hailed as "a genuinely innovative concept." ${ }^{33}$ As such, the success of the review process partly depends on

28 Human Rights Council Decision 11/110, U.N. Human Rights Council, Report of the Human Rights Council on its eleventh session, 56, U.N. Doc. A/HRC/11/37 (Oct. 16, 2009) ("The Human Rights Council . . . adopts the outcome of the universal periodic review on China which is constituted of the report of the Working Group on the review of China (A/HRC/11/25), together with the views of China concerning the recommendations and/or conclusions, as well as its voluntary commitments and its replies presented before the adoption of the outcome by the plenary to questions or issues that were not sufficiently addressed during the interactive dialogue in the Working Group (A/HRC/11/37, chap. VI)").

29 On "peer review" as opposed to "periodic review," see Gaer, supra note 16.

30 Requirements of Human Rights Council Res. 5/1, supra note 18.

31 G.A. Res. 60/251, supra note 2, 5(e).

32 Eric Neumayer, Do International Human Rights Treaties Improve Respect for Human Rights?, 49 Journal of Conflict Resolution 925-26 (2005).

33 Navanethem Pillay, Human rights in United Nations action: Norms, institutions and leadership, European Human Rights Law Review 1, 5 (2009); see also, Nazila Ghanea, From UN Commission on Human Rights to UN Human Rights Council: One step forward or two steps sideways?, INTERNATIONAL COMPARATIVE 
how states respond to the call to review other states' human rights performances and, of course, how states react to comments made to them during their own review. This was not easy to predict as the system is arguably without precedent. Peer review, whilst not unique, is not completely unknown in transnational and regional organisations. However, the system operationalised by the Human Rights Council is without parallel in terms of geographical remit, ${ }^{34}$ subject matter ${ }^{35}$ and because it is mandatory. ${ }^{36}$

Literature analyzing aspects of this new mechanism is emerging. Reviewing the first session, Redondo observes that many interventions were positive, congratulatory "pats-on-the-back" for states. ${ }^{37}$ Meanwhile, Abebe considers the first two universal periodic review sessions, noting the power of regional alliances in issuing "shaming" criticisms and congratulatory comments during the interactive dialogue (his specific focus was African states though the phenomenon can be observed outwith that region), ${ }^{38}$ whilst Ramcharan notes that the process has "one Achilles heel: many member states with atrocious human rights records are treated by their peers with kid gloves." ${ }^{39}$ Arguably this adds weight to the fears expressed by the Like Minded Group - their warning of "the condemn

Law Quarterly 695, 704 (2006); though see Alston, supra note 7, and Ladan Rahmani-Ocora, Giving the Emperor Real Clothes: The UN Human Rights Council, 12 GLOBAL GOVernance 15 (2006) (noting an earlier, similar (failed) UN peer review initiative).

34 The African Peer Review Mechanism, in contrast, is regional and voluntary. See generally, African Peer Review Mechanism, www.aprm-au.org; and more specifically, see, e.g., Magnus Killander, The African Peer Review Mechanism and Human Rights: The first reviews and the way forward, 30 Human Rights QUARTERLY 41 (2008).

35 No other such mechanism focuses on all human rights.

36 The IMF and OECD systems are voluntary, as indeed is the African peer review system.

37 Elvira Domingues Redondo, The Universal Periodic Review of the UN Human Rights Council: An assessment of the first session, 7 Chinese JOURNAL OF INTERNATIONAL LAw 721, 731 (2008).

38 Allehone M. Abebe, OfShaming and Bargaining: African States and the Universal Periodic Review of the United Nations Human Rights Council, 9 Human Rights LaW Review 1, 19 et seq. (2009).

39 Bertrand Ramcharan, The UN Human Rights Council 64 (2011). 
and the condemned" as quoted above although Alston considers that the very concept of universal periodic review responds to previous criticisms of both the Like Minded Group and western countries. ${ }^{40}$ They argued that this would be counter-productive to the goal of encouraging states to improve the human rights situation. Certainly a less flexible, "pass/fail" style, approach is not likely to prove an incitement to states. The public nature of universal periodic review (as noted above all documentation is in the public arena and available free online in official languages) inevitably means states wish at least to be seen to comply with the process and with the applicable standards. The inherent vagueness of some human rights standards assists in this respect. However, care must be taken to ensure that the process is meaningful and promotes progress, rather than just a mere paper exercise.

Sweeney and Saito approach the first two sessions from an NGO perspective, raising a number of issues concerning state selectivity of topics raised during the reviews, and a general vagueness of future activity based on review outcomes to improve human rights on the ground. ${ }^{41}$ This proved prescient and will be picked up later in this article. Naturally, the process is inter-governmental; thus it is not feasible to eradicate politicization when the membership of the Council remains states. Nevertheless, universal periodic review should include a wider range of participants than is the case in other inter-state mechanisms as other stakeholders, including NGOs, should be involved at the stage of drafting national state reports, contributing to the stakeholders report compiled by the Office of the High Commissioner for Human Rights, and reviewing the working group's report during the Human Rights Council session and, of course, at the implementation of the review's accepted recommendations and voluntary commitments undertaken by the state within the territory of the State concerned. ${ }^{42}$

In terms of the enabling resolution, the universal periodic review process is expected not to present an excessive burden to states, rather

40 SHA, supra note 9; Alston, supra note 7.

41 Gareth Sweeney \& Yuri Saito, An NGO Assessment of the New Mechanisms of the UN Human Rights Council, 9 Human Rights Law Review 203 (2009).

$42 I d$. (expressing caution over the effectiveness of this, based on their observations of the initial two sessions of review). 
it is promulgated as complementary to the existing treaty monitoring process, something "extra" and worthwhile. ${ }^{43}$ Few states have ratified and submitted timely reports to all the core U.N. human rights treaty bodies; thus the Human Rights Council has a much wider remit than the treaty bodies. Moreover, as the universal periodic review process is based on the Charter of the U.N., the Universal Declaration of Human Rights and voluntary pledges and commitment made by the state under review, as well as the treaties to which it is party, ${ }^{44}$ the scope is considerably broader than that of the treaty bodies. Indeed, Gaer argues that universal periodic review could provide added value and complements the treaty bodies. ${ }^{45}$ His analysis is based on the initial review sessions, thus no comment was possible on how the review outcomes would be used by treaty bodies and the effect they could have. In any event, it appears that little use is made of review outcomes before the treaty bodies although there is some evidence of states (including China) using selective treaty reports as a basis for questions and comments during interactive dialogues. ${ }^{46}$

For the current paper, China will provide a vehicle for examining the review process and the non-confrontational stance espoused by the Like Minded Group it headed. Like every other U.N. member state, China can participate in the universal periodic review process in two ways: as a reviewee, in accordance with the prepared schedule; and as a reviewer. The

43 "[C]omplement and not duplicate the work of the treaty bodies" quoted in G.A. Res. 50/261, supra note 2, ๆ 5(e).

44 Human Rights Council Res. 5/1, supra note 18, 91.

45 Gaer, supra note 16, at 136.

46 China cited treaty body reports and those of special procedures with respect to Japan. See, e.g., U.N. Human Rights Council, Report of the Working Group on the Universal Periodic Review Japan, 18, U.N. Doc. A/HRC/8/44 (May 30, 2008). On reservations, for example, China welcomed Mauritania's withdrawal of its reservation to CEDAW. See U.N. Human Rights Council, Report of the Working Group on the Universal Periodic Review Mauritania, 68, U.N. Doc. A/HRC/16/17 (Jan. 4, 2011). On ratifications, for example, China's recommended that Norway consider ratifying the Convention on the Rights of Persons with Disabilities. See U.N. Human Rights Council, Report of the Working Group on the Universal Periodic Review Norway, 105(2), U.N. Doc. A/HRC/13/5 (Jan. 4, 2010). 
focus of this article is on China as a reviewer, however, it is pertinent to first reflect on China's experience as a reviewee.

\section{CHINA UNDER REVIEW}

China was itself reviewed during the fourth session of the first cycle of review. Its working group was notable as it attracted one of the largest number of intervening states of the entire first cycle. ${ }^{47}$ Of the one hundred and fifteen states who sought to comment, sixty were permitted to participate in the interactive dialogue with some fifty-five "timed out" (as noted above there are strict time limits to ensure equality of treatment of all states ${ }^{48}$ ) though offered the opportunity of contributing in writing through the intranet. In keeping with the then prevailing practice, China was reviewed whilst serving as a member of the Human Rights Council. ${ }^{49}$ That China's working group dialogue attracted considerable interest is not surprising, the notable distinction between more critical comments by Western European and Others Group (WEOG) and East European EU member states and more positive supportive comments by almost every other state perhaps was. Several states expressed concern and regret at the politicization of human rights situation in China during the review process. ${ }^{50}$ In the case of

47 Shortly thereafter, the modalities were adjusted and a maximum of sixty states was rarely permitted within the time frame of the "face-to-face" interactive dialogue.

48 For summaries on the treatment of People's Republic of China as compared to Nauru, see Rhona Smith, Equality of "Nations Large and Small": Testing the theory of the universal periodic review in the Asia-Pacific, 11 Asia-Pacific Journal on Human Rights and The Law Review 36 (2011).

49 Human Rights Council Res. 5/1, supra note 18, Annex 8, stipulated that each state should be reviewed when a member of the Council. This provision has been removed. Human Rights Council Res. 16/21, 4, U.N. Doc. A/HRC/RES/16/21 (Apr. 12, 2011), provides for the order of review established for the first cycle to be maintained; equitable periodicity thus takes precedence over reviewing States during tenure at the Council.

50 For examples of countries commenting on the politicization of human rights in China and/or the review process, see U.N. Human Rights Council, Report of the Working Group on the Universal Periodic Review China, 33 (comments by Algeria), 39 (comments by Sri Lanka), 88 (comments by Pakistan), 94 (comments by Myanmar), U.N. Doc. A/HRC/11/25 (Oct. 5, 2009). 
China, arguably the result of the review was, in places, "a thinly veiled and fairly coordinated challenge to certain practices - [especially] in China's case its retention and use of capital punishment," ${ }^{51}$ the Western European and Others Group being particularly vocal in this regard. Of course, China retains the death penalty and has not ratified any human rights treaty which expressly prohibits its continued use (assuming compliance with minimum standards); thus technically it is not required in law to stop the practice. Perhaps this partially explains why China did not accept a number of the recommendations made during its review. McMahon and Ascherio classified all recommendations during the first six sessions of the review cycle with reference to the degree of action required of the state under review to fulfil any given recommendation. They then analysed the number of each classification of recommendation which was accepted by the states in the various U.N. regional groupings, highlighting some individual states. In the case of China, they note that China "accepted all forty-one of Asia and Africa's recommendations, thirty-eight of which fell into categories [requiring continuation of existing good practice, sharing of information and practice, general acceleration of practices] (by contrast, China only accepted eight of WEOG's [Western European and Others Group] sixty-nine recommendations, two-thirds of which were in categories [requiring the state to consider change or undertake specific action to effect change])." 52 As noted above, many of these WEOG recommendations related to the death penalty. The actual non-acceptance rate is thus arguably less than the statistics would suggest. Nevertheless, the death penalty was not the sole topic on which China received Western European and Others Group's recommendations. Perhaps the most noteworthy (for the present purpose) statistic is the acceptance rate of those recommendations praising Chinese practices and progress as, in the next section, the article will note that China itself generally contributes such positive, supportive recommendations to the reviews of other states. This suggests either such an approach has an effective impact on the Chinese government, or such comments are easily

51 Rhona Smith, More of the Same or Something Different? - Preliminary Observations on the Contribution of Universal Periodic Review with Reference to the Chinese Experience, 10 Chinese Journal of International Law 565, 586 (2011).

52 Edward McMahon \& Marta Ascherio, A Step Ahead in Promoting Human Rights? The Universal Periodic Review of the UN Human Rights Council, 18 Global Governance 231, 245 (2012). 
achieved and thus almost devoid of meaning as a mechanism for improving human rights on the ground.

China states that it had "undertaken its first Universal Periodic Review with an open and frank attitude and in a highly responsible manner." 53 This is obviously a subjective viewpoint but there can be little doubt that China's participation was perhaps more proactive than some detractors may have anticipated, with China even considering and responding to criticism levied by other states. ${ }^{54}$ Despite such international comments and external praise, ${ }^{55}$ the review was largely absent in national (Chinese) press, with reporting restricted to acknowledgement of the positive comments made by a large number of states. ${ }^{56} \mathrm{China}$ is by no means unique in

53 Note verbale, supra note 13, at annex; Aide Memoire, infra note 61, 4.

54 ee, e.g., Report of the Working Group on the Universal Periodic Review China, supra note 50, for comments made by France which drew on the stakeholders' reports to query various confinement practices as well as making recommendations on media practices and the death penalty ( $(56)$ while the UK expressed concern over the use of the death penalty, issues related to the Tibetan Autonomous Region and media freedom ( $\mathbf{9} 42$ ).

55 See, e.g, Report of the Working Group on the Universal Periodic Review China, supra note 50, in which Mexico welcomed China's efforts in the area of human rights and the early achievement of the millennium development goals (ף 38), South Africa welcomed the achievement of the Millennium Development Goals and China's collaboration with the OHCHR ( $(40)$, Sri Lanka praised China's history effusively (39), UAE commended China's progress and policy of openness and reform (\$ 53) and Iran commended China's strong commitment to human rights (ף 59). Even Western European and Others Group states included praise in their interventions. See, e.g., the initial comments by Australia ( $(\mathbf{1} 27)$, Canada (

56 For the official English language newspaper reports, see Human Rights Discourse, China Daily, Feb. 11, 2009, available at http://www.chinadaily.com.cn/ cndy/2009-02/11/content_7463263.htm, reporting on the first review and mention made further in Rights of Women, Kids, Elderly, Disabled Ensured, CHInA DAILY, Apr. 14, 2009, available at http://www.chinadaily.com.cn/cndy/2009-04/14/ content_7673716.htm. 
this regard. Few states evidence detailed reports in popular media on the process or indeed on other U.N. treaty body procedures.

Overall China's experience was comparable to those of many other states. The comments received were if anything more positive when viewed in comparison to the reviews of other states - indeed China was the most positively rated Asian group country. ${ }^{57}$ There is thus arguably some evidence of states queuing up to praise China's progress, ${ }^{58}$ echoing the concerns of Abebe, Ramcharan and others. ${ }^{59}$ However, there was also, indeed, some evidence of politicisation, albeit not as much as perhaps was feared. ${ }^{60}$

\section{CHINA AS A REVIEWER STATE}

China's putative approach to the work of the Human Rights Council was indicated in the Aide Memoire submitted in 2006 to support China's initial candidature for the Human Rights Council. ${ }^{61}$ Therein China notes that

... the Human Rights Council should respect the historical, cultural and religious backgrounds of different countries and regions; . . . attach equal importance to civil and political rights on the one hand and economic, social and cultural rights on the other/ the Council should ensure impartiality, objectivity and non-selectivity in the consideration of human rights issues, and the elimination

57 All reviews of all States have been coded positive or negative. Thus it is possible to comment on the review of China against the wider context of the entire first cycle.

58 Very positive reviewers of China include the Report of the Working Group on the Universal Periodic Review China, supra note 50, 29 (comments by Singapore), $\mathbf{g}$ 41 (comments by Saudi Arabia), 50 (comments by Viet Nam), 55 (comments by India), 93 (comments by Thailand), 91 (comments by Colombia).

59 See Abebe, supra note 38, Ramcharan, supra note 39; Rosa Freedman, New Mechanisms of the UN Human Rights Council, 29 Netherlands Quarterly of Human Rights 289 (2011).

60 Several States commented on the politicisation of China's review although there was limited mention of sensitive issues such as the Tibetan Autonomous Region / Tibet and the Uighyurs in Xinjiang (NW China). Supra note 54.

61 Aide Memoire for 2006 inaugural candidature of China to the Human Rights Council, available at http://www.un.org/ga/60/elect/hrc/china.pdf. 
of double standards and politicization. ${ }^{62}$

This statement reflects the views previously expressed by the Like Minded Group and which, as noted above, find expression in the enabling resolutions. Three years later, when presenting for re-election, China pledged to continue "to take an active part in the work of the Human Rights council and the Third Committee of the General Assembly, ... encouraging the above-mentioned institutions to deal with human rights issues in a fair, objective and non-selective manner." 63 There is little scope to claim that China failed to deliver on its promised involvement in the Council. However, notwithstanding that fact, it is possible to question the impact of China's involvement - whether it contributed towards the improvement of the human rights situation in states.

China has proven to be a very active reviewer state, participating in the interactive dialogue of virtually every working group during the first cycle of the review process (and indeed, the initial review of the second cycle). ${ }^{64}$ This article considers every intervention made by China during the first cycle of universal periodic review. To do this, the reports of each working group were examined, with China's comments isolated. The principal topics mentioned, even in passing, were identified and listed. A table of subjects of most interest to China thus emerged. The frequency with which China mentioned these most repeated topics is reflected in Figure 1 (Comments by China). Note that no judgment is made as to whether China was supportive or positive in respect of any single topic for this chart, simply the mention of the topic itself was sufficient. Moreover, each topic is only recorded once, even if China makes repeated mentions of it within any particular report. This provides the data for the following analysis.

\section{a. Topics Addressed by China}

In general, a disparate range of topics are covered in each review, occasionally a single topic proves especially popular - e.g. the death penalty

62 Aide Memoire, supra note 61, at 9.

63 Note verbale, supra note 13 , at point 4.

64 China did not comment on very few States and was timed out of commenting on a further six (Singapore, Lebanon, Turkey, Italy, Qatar and Nicaragua), though, of course, for those States it could file comments, questions and recommendations on the intranet. 


\section{FIGURE 1}

\section{China and UPR topics}

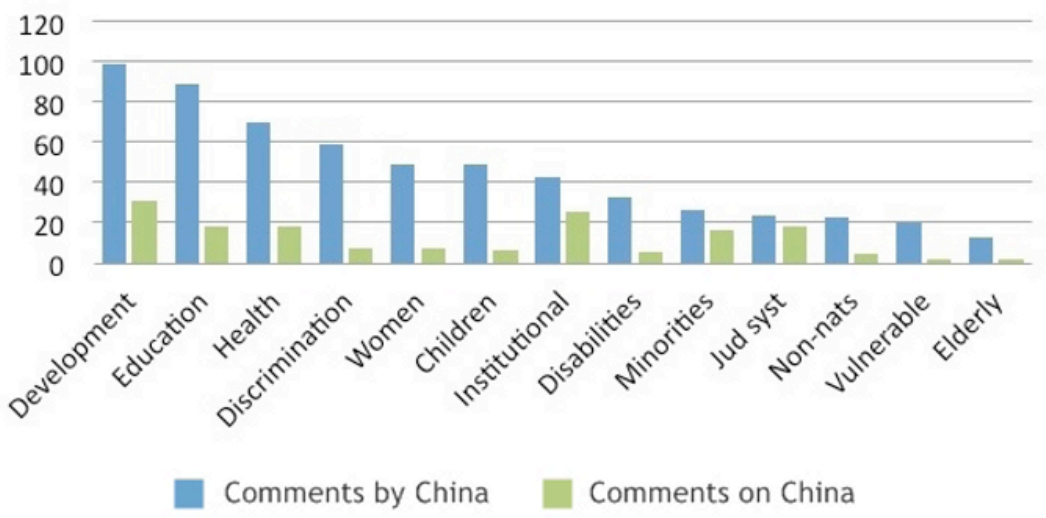

during China's first review, as noted above. Ramcharan notes a "scattershot process" ${ }^{\prime 5}$ to the selection of topics by member states. This is perhaps inevitable as the human rights situation is, of course, different in each states. A reviewing state is thus likely to identity different issues in different states. China certainly does this, although the data suggests the prevalence of certain topics.

As can be seen (figure one), development issues feature most prominently in the list of topics the Chinese delegation chose to focus on. In this category, fulfilment of the millennium development goals, economic development, social progress, poverty and employment are categorized together. Such issues were raised by China in over ninety periodic reviews. China's emphasis on poverty and development, health and education is perhaps unsurprising. There are two strands of explanation- firstly, that these are rights China considers crucially important and thus prioritises or secondly, these are rights which China itself fulfils to a greater rather than lesser degree.

On the former, China has long been a proponent of the preeminence of basic survival rights such as food, housing, healthcare and the development 
through education within a strong institutional structure. ${ }^{66}$ These are also rights which appear in China's first National Human Rights Action Plan 2009-2010, ${ }^{67}$ a two year plan published following, but intimated during, China's own periodic review. ${ }^{68}$ Perhaps they are thus "soft" options upon which China can comment from a relative position of strength, whilst still accepting advice on good practice to further develop its own position. A number of states commented positively on China's progress on development and its fulfilment of the millennium development goals. ${ }^{69}$

The use of universal periodic review as a tool for securing the advancement of economic, social and cultural rights has been questioned and examined by Duggan-Larkin. ${ }^{70}$ She notes that there is a degree of selectivity evident in the initial years of the process, least developed states facing far more questions on economic, social and cultural rights than developed states. ${ }^{71}$ This pattern certainly continued throughout the first cycle and appears to have continued in the initial session of the second cycle. China, however, did raise such issues irrespective of the development status of the country under review, ${ }^{72}$ although poverty and "development" are un-

66 White Paper Human Rights in China 1991, supra note 5, Part I, notes that the right to subsistence is the foremost human right the Chinese people fight for.

67 National Human Rights Action Plan for China 2009-2010, the Information Office of State Council, 2009 and indeed, subsequently appear in the second national plan of action 2012-2015 available online in English translation, available at http:// news.xinhuanet.com/english/china/2012-06/11/c_131645029.htm.

68 This was welcomed during the working group. See, e.g., Report of the Working Group on the Universal Periodic Review China, supra note 50, 30 (comments by Netherlands), 33 (comments by Algeria), 44 (comments by Uzbekistan).

69 See, e.g., supra notes 55, 58.

70 Jessica Duggan-Larkin, Can an Intergovernmental Mechanism Increase the Protection of Human Rights? The Potential of Universal Review in Relation to the Realisation of Economic, Social and Cultural Rights, 28 NeTHERLANDS QUARTERLY of Human Rights 548 (2010).

$71 \quad$ Id. at 576.

72 For examples of China's participation in the reviews of developed States, see, e.g., U.N. Human Rights Council, Report of the Working Group on the Universal Periodic Review Canada, ๆ 66, U.N. Doc. A/HRC/11/17; U.N. Human Rights Council, Report of the Working Group on the Universal Periodic Review New Zealand, 9 64, U.N. Doc. A/HRC/12/8; U.N. Human Right Council, Report of the Working 
doubtedly more frequently mentioned in respect of less developed states. The fact that economic, social and cultural rights are often "progressively realisable" leads to a necessary flexibility in defining standards. ${ }^{73}$ There are obvious benefits for progressively realizable rights should additional technical assistance be forthcoming. This issue is frequently mentioned by China, calling for technical assistance in the reports of several states, including Mauritania, ${ }^{74}$ Democratic Republic of the Congo ${ }^{75}$ and Afghanistan. ${ }^{76}$ It will be interesting to discover whether technical assistance has been offered, with those more developed states using the UPR process to channel their resources. The evidence so far (from interim reports) is not especially positive, but the reality will only become apparent as the second cycles reports emerge - part of the focus of the second cycle is to

Group on the Universal Periodic Review United States of America, 9 21, U.N. Doc. A/HRC/16/11. All make reference to economic and social rights, including health and education.

73 This will prove interesting when the Optional Protocol to the Covenant on Economic, Social and Cultural Rights enters into force. See, e.g., Malcolm Langford, Closing the Gap? - An Introduction to the Optional Protocol to the International Covenant on Economic, Social and Cultural Rights, 27 Nordisk Tidsskrift for Menneskrettigheter 1 (2009); Claire Mahon, Progress at the Front: The Draft Optional Protocol to the International Covenant on Economic, Social and Cultural Rights, 8 Human Rights Law Review 617 (2008). For earlier discussions, see, e.g., Michael Dennis and David Stewart, Justiciability of Economic, Social and Cultural Rights: Should there be an international complaints mechanism to adjudicate the right to food, water, housing and health?, 98 AMERICAN JOURNAL OF International Law 462 (2004); Philip Alston, No Right to Complain about being Poor: The need for an Optional Protocol to the Economic Rights Covenant, in The Future of Human Rights ProteCtion IN A CHANGING WORLD (A. Eide \& Elgesen eds., 1991).

74 U.N. Human Rights Council, Report of the Working Group on the Universal Periodic Review Mauritania, 68, U.N. Doc. A/HRC/16/17 (Jan. 4, 2011).

75 U.N. Human Rights Council, Report of the Working Group on the Universal Periodic Review Democratic Republic of the Congo, 65, U.N. Doc. A/HRC/13/8 (Apr. 1, 2010).

76 U.N. Human Rights Council, Report of the Working Group on the Universal Periodic Review Afghanistan, 74, U.N. Doc. A/HRC/12/9 (July 20, 2009). 
consider "the implementation of the accepted recommendations and the development in the human rights situation in the state under review." 77 As states do not generally refute offers of technical assistance or recommendations that technical assistance be sought, this could prove informative as to whether assistance was forthcoming and had any benefit for human rights on the ground.

On the second strand (that China itself adequately fulfils the rights raised), China is a proponent of the right to development and related rights. Indeed China commenced its own interactive dialogue in its working group session by highlighting the fact it is the largest developing state in the world. ${ }^{78}$ China has ratified relevant core treaties such as the International Covenant on Economic, Social and Cultural Rights. Moreover, in terms of the UNDP's Human Development Index, China has a notable positive trajectory over the last thirty years. ${ }^{79}$ China also secured early achievement of Millennium Development Goals. China has a good record of achievement in respect of development, making substantial progress towards achieving and now surpassing the Millennium Development Goals, a key indicator of development. ${ }^{80}$ Within the U.N., the Chinese government have long participated in the evolution (from conceptualisation to adoption) of the Declaration on the Rights to Development and regularly co-sponsored the former Commission on Human Rights' resolutions on the right to development. In the words of the State Council's 1991 White Paper, "China pays close attention to the issue of the right to development." Support for development has continued since the collapse of the Commission. Finally, China has education and health as focal points for its current governmental strategies, which, in human rights terms, find expression in the first (and indeed now also second) national plan of action for human rights.

77 G.A. Res. 65/281, supra note 2, at annex, C.1.6.

78 Report of the Working Group on Universal Periodic Review China, supra note $50, \mathrm{~g} 18$.

79 UNDP Human Development Index, China, available at http://hdrstats.undp.org/ en/countries/profiles/CHN.html.

80 See, e.g., Ministry of Foreign Affairs of the People's of Republic of China, China's Progress Towards the Millennium Development Goals Report 2010, available at http://www.undp.org/content/dam/undp/library/MDG/english/ MDG\%20Country\%20Reports/China/China_MDGReport_2010.pdf. 
Overall, social progress including education and health are central tenets of government policy.

Whilst it is undoubtedly easier to manoeuvre standards and espouse differing views of progress in respect of economic, social and cultural rights as opposed to instantly realizable and challengeable civil and political rights, China does comment on a number of issues concerning judicial reform in, for example, Poland ${ }^{81}$ and Bahrain, ${ }^{82}$ and the status and condition of prisons and detainees during reviews of various states including Zambia, ${ }^{83} \mathrm{Cuba}^{84}$ and Malta. ${ }^{85}$ It even comments on the internet, expression and the need to control pornographic material during the review of the Netherlands. ${ }^{86}$ Of course, China itself prioritises judicial reform in its national action plans and other domestic initiatives and makes claims on progress in, inter alia, its national plan of action and its statement to the working group undertaking its own review. ${ }^{87}$

Thus there is evidence that China elects to comment across the full range of human rights ${ }^{88}$ not simply economic and social rights. Admittedly,

81 U.N. Human Rights Council, Report of the Working Group on Universal Periodic Review Poland, ๆ 42, U.N. Doc. A/HRC/8/30 (May 23, 2008).

82 U.N. Human Rights Council, Report of the Working Group on Universal Periodic Review Bahrain, ๆ 33, U.N. Doc. A/HRC/8/19 (June 9, 2008).

83 U.N. Human Rights Council, Report of the Working Group on Universal Periodic Review Zambia, ๆ 12, U.N. Doc. A/HRC/8/43 (June 2, 2008).

84 U.N. Human Rights Council, Report of the Working Group on Universal Periodic Review Cuba, ๆ 66, U.N. Doc. A/HRC/11/22 (May 29, 2009).

85 U.N. Human Rights Council, Report of the Working Group on Universal Periodic Review Malta, ๆ 63, U.N. Doc. A/HRC/12/7 (June 4, 2009).

86 U.N. Human Rights Council, Report of the Working Group on Universal Periodic Review Netherlands, ๆ 46, U.N. Doc. A/HRC/8/31 (May 31, 2008). See also, U.N. Human Rights Council, Report of the Working Group on Universal Periodic Review Mauritius, ๆ 69, U.N. Doc. A/HRC/11/28 (Mar. 3, 2009).

87 National Action Plan, supra note 67. See also, Report of the Working Group on Universal Periodic Review China, supra note 50, ๆๆ 9-11. Of course, external bodies debate China's progress in some of these fields.

88 See, e.g., U.N. Human Rights Council, Report of the Working Group on Universal Periodic Review Cameroon, ๆ 15, U.N. Doc. A/HRC/11/21 (May 29, 2009) (comments by the Chinese delegation on fair trial rights in Cameroon); U.N. 
the most common issue raised which can come under civil and political rights is discrimination and the treatment of women and children - these issues of course appear not only in the International Covenant on Civil and Political Rights, which China has not yet ratified, ${ }^{89}$ but also in the Conventions on Elimination of Discrimination against Women and on the Rights of the Child which it has. The prohibition on discrimination is, of course, pervasive; thus it applies also to economic, social and cultural rights. As figure 1, series 1 shows, after development (discussed above) China commented most frequently on education, health and discrimination. China has made significant gains in education and health, not least as evidenced by China's success in meeting millennium development goals in those areas. Discrimination, as noted above, is pervasive. China has commented on discrimination in a number of fields, including gender, national minorities, and the urban/rural differentiation of enjoyment of rights. Women and children also featured prominently, in almost fifty reviews. Both topics were often raised at once, perhaps indicating China's view that similar issues beset each group. Obviously, China has ratified both the Convention on the Elimination of All Forms of Discrimination against Women and the Convention on the Rights of the Child, and thus

Human Rights Council, Report of the Working Group on Universal Periodic Review Monaco, ๆ 61, U.N. Doc. A/HRC/12/3 (June 4, 2009) (torture in Monaco); U.N. Human Rights Council, Report of the Working Group on Universal Periodic Review Cambodia, ๆ 48, U.N. Doc. A/HRC/13/4 (Jan. 4, 2010) (land reform in Cambodia); U.N. Human Rights Council, Report of the Working Group on Universal Periodic Review Egypt, ๆ 51, U.N. Doc. A/HRC/14/17 (Mar. 26, 2010) (corruption); U.N. Human Rights Council, Report of the Working Group on Universal Periodic Review Mongolia, 40, U.N. Doc. A/HRC/16/5 (Jan. 4, 2011) (environment).

89 In China's first commitments and pledges lodged when seeking membership of the inaugural Human Rights Council, China stated it was "in the process of amending its Criminal Civil and Administrative Procedure Laws and deepening judicial reform to create conditions for ratification at an early date." Aide Memoire, supra note 61 , at IV. This disappeared from the pledges and commitments tendered in support of its re-election in 2009. Note verbale, supra note 13. The second national human rights action plan 2012-2015, published June 2012, notes only that China "has continued to carry out administrative and judicial reforms and prepare the ground for approval of the "International Covenant on Civil and Political Rights."” National Human Rights Action Plan of China (2012-2015) at part V, 1, supra note 67. 
can mention women and children as key issues, reflecting ratifications of China and other states, as well as issues of concern for the U.N. generally. ${ }^{90}$ With respect to treaty obligations, China does not systematically refer to the treaty ratification status and reporting obligations of states. However, there is evidence of China referring to treaty ratifications during the working group dialogues. ${ }^{91}$ In each of these instances, China is referring to treaties which the state has already signed or indicated a willingness to accept. Already, the High Commissioner on Human Rights has noted the positive effect of universal periodic review on treaty ratifications ${ }^{92}$ arguably China could thus have made more recommendations concerning treaty ratification thereby demonstrating a first step towards impact on human rights. On cooperation with the Council, other human rights bodies and the OHCHR, China did make several relevant comments. For example, China commented on participation with the U.N. treaty bodies

90 For example, the U.N. created the U.N. Women (http://www.unwomen.org) as an umbrella to support women's empowerment and gender equality. Gender mainstreaming remains aspirationally embedded in all U.N. activities. Children are considered regularly by the U.N. General Assembly. Most recently, the third optional protocol to the Convention on the Rights of the Child was adopted, extending the right of individual communication to victims of infringements of that convention.

91 See, e.g., U.N. Human Rights Council, Report of the Working Group on the Universal Periodic Review Jamaica, ๆ 70, U.N. Doc. A/HRC/16/14, (Jan. 4, 2011); U.N. Human Rights Council, Report of the Working Group on the Universal Periodic Review USA, supra note 72, ๆ 21; U.N. Human Rights Council, Report of the Working Group on the Universal Periodic Review Marshall Islands, ๆ 29, U.N. Doc. A/HRC/16/12 (Apr. 18, 2011); U.N. Human Rights Council, Report of the Working Group on the Universal Periodic Review Niger, ๆ 60, U.N. Doc. A/HRC/17/15 (Mar. 25, 2011).

92 The Secretary-General, United Nations Reform, Measures and Proposals: Note by the Secretary-General, p. 18, delivered to the General Assembly, U.N. Doc. A/66/860 (June 26, 2012) (a note by the Secretary-General introducing the Report of the UN High Commissioner for Human Rights on the Strengthening of the Human Rights Treaty Bodies). 
for several states, including Indonesia, ${ }^{93}$ Czech Republic, ${ }^{94}$ and Tunisia. ${ }^{95}$ Once again, however, it stopped short of clear criticism of shortcomings. China itself pledged to fulfil its treaty obligations, "submit timely reports on implementation, and conduct constructive dialogues with relevant treaty bodies" ${ }^{\prime 6}$ thus (again) is not commenting on anything it does not already claim it does.

\section{b. Nature of Comments Made by China}

What is particularly striking when reviewing all China's interventions is the positivity of China's contributions. Thus in very few situations does China request a state to undertake any positive action. ${ }^{97}$ Rather, the Chinese government's active interventions tend to suggest a state share its experiences (thus highlighting good practice) or simply respond to requests for further information. Indeed, when all comments made by all states are rated positive or negative, to the same criteria, China is the most positive Asian participant and, indeed, one of the most positive of all states participating in the review process. ${ }^{98}$ This arguably demonstrates China's understanding that the process should be constructive and non-

93 U.N. Human Rights Council, Report of the Working Group on the Universal Periodic Review Indonesia, 90, U.N. Doc. A/HRC/21/7 (July 5, 2012).

94 U.N. Human Rights Council, Report of the Working Group on the Universal Periodic Review Czech Republic, g 30, U.N. Doc. A/HRC/8/33 (May. 23, 2008).

95 U.N. Human Rights Council, Report of the Working Group on the Universal Periodic Review Tunisia, 20, U.N. Doc. A/HRC/21/5 (July 9, 2012).

96 Note verbale, supra note 13, annexe at point 4.

97 In initial working group reports, the full comment including recommendations of the intervening state was noted in one paragraph, the recommendations being extracted at the end. In later reviews, the comments appear in order but the recommendations are extracted and only appear at the end of the report, with the State making the recommendation noted. It is thus possible to ascertain whether any State is deemed to have made recommendations, irrespective of the year of the review.

98 China's most negative interventions are in respect of the United States of America, see Report of the Working Group on Universal Periodic Review, United States of America, supra note 72, 21; and St Lucia, see U.N. Human Rights Council, Report of the Working Group on Universal Periodic Review, Saint Lucia, 9989.57 , 89.62, U.N. Doc. A/HRC/17/6 (Mar. 11, 2011). 
confrontational ${ }^{99}$ and should ensure fulfilment of the objective of review specified by the Human Rights Council, ${ }^{100}$ including the sharing of best practices. This China frequently does. Given the disparate human rights situations around the world, it is appropriate to question China's approach: will positive rhetoric really achieve the first objective of the review, viz. "[t]he improvement of the human rights situation on the ground," indeed, other objectives such as "fulfillment of the State's human rights obligations" ? ${ }^{102}$ If no positive recommendations are made to seek international aid and technical assistance, even those comments of China related to that may not achieve their goal.

Some political commentators characterise China's attitude towards human rights (and other international issues) as "soft power"103 - a relatively subtle diplomatic exercise, little by little extending influence and reach through non-confrontational means, demonstrating by doing, rather than pontificating. By focussing on positives and on development issues, China is well-placed to succeed with such an approach, choosing topics in which it arguably can claim to lead by example. In human rights terms, this reflects a pragmatic approach - the process is engaged with without delivering (and conversely, inviting) criticism. In any case, it is well-established that states are, traditionally, unwilling to comment on the human rights situation in another state unless either their nationals are involved ${ }^{104}$ or the situation is such that it could either spill over into their territory (should the state be a neighbour) or threaten international peace and security.

\section{EVALUATION OF CHINA'S CONTRIBUTION}

To determine the contribution made by China to the review process, it is useful to first revisit the objectives of the first cycle of review. These were

99 As noted above, see Human Rights Council Res. 5/1, supra note 18, annexe 3(g), and the view of the Like Minded Group.

100 Human Rights Council Res. 5/1, supra note 18, annex 4.

101 Id. at $4(\mathrm{a})$.

$102 I d$. at $4(\mathrm{~b})$.

103 See, e.g., Joshua Kurlantzick, Charm Offensive: How China's soft power IS TRANSFORMING THE WORLD (Yale University Press 2007), for a fairly polemical view of China's rise against, in particular, the United States.

104 It thus becomes an issue of direct concern to the state. 
stated as being improving the human rights situation and advancing the fulfilment of the state's human rights obligations as noted above, ${ }^{105}$ as well as enhancing the state's capacity and technical assistance, sharing of best practice, support for cooperation and encouragement of engagement with the Council, other human rights bodies and the Office of the High Commissioner for Human Rights. ${ }^{106}$ First and foremost, universal periodic review should have a demonstrable effect on human rights in every state, as noted above, it should not be simply a paper exercise. There are, of course, many different options for analysing the interventions made by China within the first cycle of universal periodic review. For the purpose of this article, the extent to which China is advancing the objectives of the review process is deemed central. This will be considered in the closing paragraphs. As a precursor, it is useful to first consider whether China's interventions are rooted in reciprocity and then the extent to which the comments reflect the tenor of the foundation U.N. documentation which tabulates the purpose of the review (General Assembly resolution 60/251 and Human Rights Council resolution 5/1).

\section{a. Is Reciprocity a Factor?}

China cannot be responding on the basis of reciprocity of comments. As noted above, China was not reviewed in the first session of the first cycle of reviews and thus commented on countries which did and did not comment on it. Furthermore, China participated in reviews of almost every state whilst (only) 115 states sought to comment on it. Obviously, maintaining such a level of involvement with the entire process allows China to monitor the mechanism by direct observation and participation. Given China's initial concerns over the process evolving into one of condemnation, rather than support, this is a sensible strategy. Moreover the topics raised by China do not necessarily reflect the topics raised by other states with respect to China (see figure 1, Comments on China). During China's own review, development issues (usually praise for China) then institutional issues (primarily ratification of treaties and institutional reforms of national bodies) were raised repeatedly. Although not shown on the comparative figure, the next most popular topic raised in comments on China was civil

105 Supra note 16 et seq.

106 Human Rights Council Res. 5/1, supra note 18, annexe 4 (a)-(f). 
and political rights drawn primarily from the International Covenant on Civil and Political Rights, to which China is not a party. Religious freedom, freedom of expression and freedom of association were frequently raised and inevitably China was criticized (as noted above, primarily by members of the WEOG group) for failing to reach the required standards. Although China has not ratified the International Covenant, it does accept, indeed its representatives helped to draft, ${ }^{107}$ the Universal Declaration of Human Rights which also proclaims expression and religion as basic freedoms. Moreover, the White Paper and the subsequent papers and national plans of action also contain detailed provision on this. ${ }^{108}$

As figure 1 shows, after development (discussed above) China commented most frequently on education, health and discrimination. These were also popular topics to raise in respect of China's review. Education and health are two issues in which China has demonstrated considerable success (again, discussed above). Discrimination is pervasive across many/ all rights and freedoms. For the purpose of figure 1, the main issues commented on involved gender-based discrimination, national minorities and discrimination of rural dwellers as opposed to urban dwellers. The latter is an acknowledged issue in China which the government claims to be addressing. ${ }^{109}$ China also regularly commented on issues concerning women and children, making interventions on each (and usually both) in some fifty state reviews. Although similar issues were raised in respect of China, the numbers of comments are far less than those on institutional issues, minorities (status of rather than discrimination) and the judicial system. Even on a state by state review, there is little evidence that China raises topics which were raised in respect of it specifically by any state.

\section{b. Are the UN Guidelines Followed?}

China's approach may be considered to follow, almost exactly, the guidance issued by the General Assembly and then the Human Rights Council. Almost every state under review has ratified the U.N. Convention on the Rights of the Child, most have also ratified the Convention on the Elimi-

107 Dr. Peng Chun Chang of China helped draft the Universal Declaration.

108 Supra note 5; National Action Plans, supra note 67.

109 National report submitted by China, U.N. Doc. A/HRC/WG.6/4/CHN/1 and national action plans, supra note 67. 
nation of Discrimination Against Women and the two international covenants (International Covenant on Economic, Social and Cultural Rights; International Covenant on Civil and Political Rights). Accordingly, under the relevant resolution, these issues fall within not only the Universal Declaration of Human Rights but also the human rights instruments to which a state is party. ${ }^{110}$ Moreover, addressing these rights and freedoms meets the objectives of improving human rights in the country under review, progressing the fulfilment of the state's human rights obligations and enhancing the state's capacity. ${ }^{111}$

China certainly made frequent reference to the need for international technical aid and assistance to help countries combat poverty and develop. ${ }^{112}$ The principal argument against such an approach is that China elected to make very few concrete recommendations to states under review, not even regularly recommending that technical assistance be sought. This can be problematic although it is acknowledged that there is a narrow line between support and interference. China has long maintained that the international community has little right to interfere in matters deemed within national sovereignty. It is thus not especially surprising that it takes a non-interventionist approach to the human rights situation within other states. ${ }^{113}$ However, does that really help the universal periodic review process improve the human rights situation on the ground? It is submitted that it does not. China's approach tends to the highlighting of good

110 Human Rights Council Res. 5/1, supra note 18, at annexe gg 1(b)-(c).

111 Id. ๆๆ 4(a)-(c).

112 See, e.g., Report of the Working Group on the Universal Periodic Review Democratic Republic of the Congo, supra note 75, ๆ 65; Report of the Working Group on the Universal Periodic Review Afghanistan, supra note 76, 74.

113 A much debated example of this is the Chinese government's negotiations based on the potential invocation of veto in the Security Council when discussing issues related to interventions in third States. For example, China abstained from the vote authorizing military enforcement of a no-fly zone ostensibly to protect civilians in Libya. Press Release, Security Council, Security Council Approves 'No-Fly Zone' Over Libya, Authorizing 'All Necessary Measures' to Protect Civilians, By Vote of 10 in Favour With 5 Abstentions, U.N. Doc. SC/10200 (Mar. 17, 2011). However, the threat of veto by China and Russia has prevented the Security Council from taking action (as of the submission of this article) in respect of Syria. In 19 July 2012, China and Russia vetoed a draft resolution on sanctions which could not then proceed to a formal resolution. 
practice with little mention, particularly when dealing with less developed states, of action conducive to the improvement of the prevailing human rights situation. However, as noted above, ${ }^{114}$ China did not accept many recommendations for concrete change within its own territory during its review. It would thus be hypocritical for the Chinese government to take a more proactive, interventionist stance towards other states. In spite of the foregoing, China did make several references to national human rights institutions. These are, of course, considered to be beneficial in promoting the protection of international human rights within states, ${ }^{115}$ although China does not have one. It is thus perhaps striking that the state chose to comment on national institutions in several working group dialogues. ${ }^{116}$ The prevailing U.N. view is undoubtedly that national human rights institutions should be encouraged. Indeed, considerable efforts are ongoing in Asia and the Pacific, for example, supporting the establishment of such bodies in states in the region.

China clearly projects a very non-confrontational stance, one which many commentators consider to be predicated on geography and/or development. McMahon and Ascherio, ${ }^{117}$ Freedman ${ }^{118}$ and Abebe ${ }^{119}$ are amongst the commentators noting a north-south divide, or to be more precise, West-

114 U.N. Human Rights Council, Final Outcome of the Universal Periodic Review, China, U.N. Doc. A/HRC/11/37 (June 3, 2009); Human Rights Decision 11/110, supra note 12; McMahon \& Ascherio, supra note 52.

115 Paris Principles relating to the Status of National Human Rights Institutions, G.A. Res. 48/134 (Dec. 20, 1993); see also, Human Rights Council Res. 9/12, U.N. Human Rights Council, UN Voluntary Goals on Human Rights, article 1(c), U.N. Doc. A/HRC/RES/9/12 (Sept. 18, 2009).

116 See, e.g., U.N. Human Rights Council, Report of the Working Group on the Universal Periodic Review Mali, g 24, U.N. Doc. A/HRC/8/50 (June 13, 2008); U.N. Human Rights Council, Report of the Working Group on the Universal Periodic Review Sri Lanka, 27, U.N. Doc. A/HRC/8/46 (June 5, 2008); U.N. Human Rights Council, Report of the Working Group on the Universal Periodic Review Cyprus, 96 , U.N. Doc. A/HRC/13/7 (Jan. 4, 2010); U.N. Human Rights Council, Report of the Working Group on the Universal Periodic Review Suriname, 51, U.N. Doc. A/ HRC/18/12 (Oct. 22, 2010).

117 McMahon \& Ascherio, supra note 52.

118 Freedman, supra note 59.

119 Abebe, supra note 38. 
ern European and Others Group augmented by EU members of the Eastern European bloc against the rest of the U.N. Western and Eastern European states are of course all subject to fairly robust human rights standards through the Council of Europe's Convention on Human Rights, overseen by the European Court of Human Rights. Other members of the Western Europe and Others Group have their own strong national systems: Canada, Australia and New Zealand, for example. A more adversarial type of approach is thus normal in these states and human rights standards prevalent in each state are regularly challenged in courts and tribunals. However, these are also relatively established, developed states, ranking amongst the highest levels of development in the world. They thus may view the periodic review process more as mechanism for fast-tracking states to higher levels of compliance with human rights than a means to discuss problems and challenges. For China, a much more literal approach is taken to ensuring the review process is cooperative, non-judgmental, etc. Whether this will result in positive changes remains to be seen. For sure, most African and Asian states take a similar approach to that evinced by China. Neumayer ${ }^{120}$ is one commentator noting the general reluctance of states to criticise each others' human rights performance. In part this reticence can be traced to a fundamental tenet of public international law - non-interference in national sovereignty, ${ }^{121}$ a doctrine China avidly supports. ${ }^{122}$

\section{CONCLUDING COMMENTS}

Without doubt China is notable in the working group reports as making very supportive and encouraging comments to some of the least developed states on earth, drawing attention to small gains and the presence of political will for change. This certainly permits China to claim credit in its promotion of human rights around the world. ${ }^{123}$ However, the lack

120 Neumayer, supra note 32.

121 U.N. Charter article 2(7).

122 See, e.g., supra note 113.

123 CHEN Dingding explores the growth of China's participation in international human rights in Dingding Chen, China's Participation in the International Human Rights Regime: A state identity perspective, 2 Chinese Journal of International Politics 399 (2009). See also, Bjorn Ahl, Statements of the Chinese Government before the Human Rights Treaty Bodies: Doctrine and practice of treaty 
of criticism and constructive comments requiring positive action belies passivity on the part of China. Arguably, it is all show - overt indication of a willingness to participate occluding a lack of engagement with proactive change agents within states. China's involvement in the process is perhaps inevitable, given how hard it lobbied for a softly approach. It would be hypocritical of it to then absolve itself of participation. Although China can, on the basis of statistics, claim to be an active participant, it is clear that China's involvement is more passive than active. China's involvement is a classic case of "much ado about nothing" - justifying a fanfare and claims of "credit" on the international stage, without any underpinning substance.

It can be averred that China's successful negotiation, on behalf of the Like Minded Group, of a more "watered-down" version of universal periodic review than perhaps would otherwise have been the case, marked China's card. It was not open to China to do anything other than go along with the new mechanism; after all, it had in effect got what it wanted and thus was under a moral obligation to demonstrate willingness. For China, this is a "win, win" situation as China's participation is unequivocal evidence of its participation in the U.N. human rights system. That China has fully engaged with the process is beyond question even although there are criticisms that China's participation has skewed the process away from a critical analysis of state performance.

At the inaugural session of the Human Rights Council, the Vice Minister of Foreign Affairs of the People's Republic of China concluded his remarks with the following words of an ancient Chinese poem: "[ $t$ he new will invariably supersede the old, and change is expected of every generation." ${ }^{24}$ The veracity of that statement with respect to international human rights monitoring in incontestable. Whether H.E. Mr Yang's aspiration that "the Human Rights Council will go farther along the right track

implementation, 12 Australian Journal of Asian LaW 82 (2012), which analyses many of the apparent inconsistencies with the approach of the government to the treaty bodies. For a general review of China's evolving role, see Bjorn Ahl, Exploring Ways of Implementing International Human Rights Treaties in China, 28 Netherlands Quarterly of Human Rights 361 (2010).

124 YANG Jiechi, Vice Minister of Foreign Affairs of the People's Republic of China at the Inaugural Session of the United Nations Human Rights Council Geneva, p. 5 (June 20,2006), available at http://www2.ohchr.org/english/bodies/hrcouncil/ docs/statements/china.pdf. 
and make greater contribution to improving human well-being" ${ }^{125}$ is less obvious. China has undoubtedly been an active and vocal participant in universal periodic review thus it would appear the Chinese government considers universal periodic review to be the "right track" for monitoring human rights. What is difficult is determining the extent to which China's positive, supportive interventions actually contribute to "improving human well being," and, of course, the "human rights situation on the ground." China has good form with active participation in universal periodic review, the substantial benefits however remain to be seen.

\section{POSTSCRIPT}

Since this article was finalised, China has been re-elected to the Human Rights Council for a full three year term (2014-2016) and has completed its second cycle universal periodic review (October 2013, working group interactive dialogue; February 2014, China's views on recommendations communicated). 